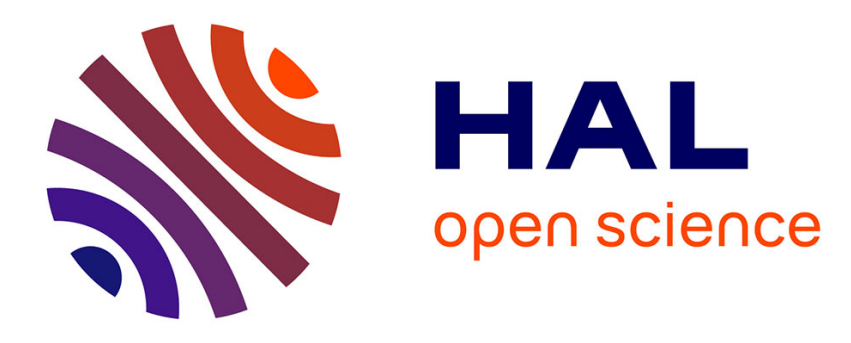

\title{
José Manuel Díaz-Cruz, Miquel Esteban, Cristina Ariño: Chemometrics in electroanalysis
}

Florence Lagarde

\section{To cite this version:}

Florence Lagarde. José Manuel Díaz-Cruz, Miquel Esteban, Cristina Ariño: Chemometrics in electroanalysis. Analytical and Bioanalytical Chemistry, 2020, 412, pp.3017-3018. 10.1007/s00216-02002522-x . hal-02512058

\section{HAL Id: hal-02512058 https://hal.science/hal-02512058}

Submitted on 30 Oct 2020

HAL is a multi-disciplinary open access archive for the deposit and dissemination of scientific research documents, whether they are published or not. The documents may come from teaching and research institutions in France or abroad, or from public or private research centers.
L'archive ouverte pluridisciplinaire HAL, est destinée au dépôt et à la diffusion de documents scientifiques de niveau recherche, publiés ou non, émanant des établissements d'enseignement et de recherche français ou étrangers, des laboratoires publics ou privés. 


\title{
José Manuel Díaz-Cruz, Miquel Esteban, Cristina Ariño: Chemometrics in Electroanalysis
}

\author{
Florence Lagarde \\ Univ Lyon, CNRS, Université Claude Bernard Lyon 1, Institute of Analytical Sciences, UMR 5280, 5 Rue \\ la Doua, F-69100 Villeurbanne \\ florence.lagarde@univ-lyon1.fr
}

Book's topic The ever increasing number and complexity of data generated by modern analytical instrumentation conjugated with the necessity to rationalize experiments and guarantee the relevance and reliability of extracted informations, have favored the emergence of a new discipline, chemometrics. Based on the application of mathematical and statistical methods to all stages of the analytical process, i.e., from the optimization of sample treatment procedure to data collection and data processing, chemometrics is widely used in a large variety of analytical areas. Unfortunately, application to the electroanalytical field is not so simple and requires the adaptation of the most common linear chemometric methods (e.g. principal component analysis, partial least squares calibration,...) or the development of new specific approaches (e.g. artificial neural networks,...).

The book Chemometrics in Electroanalysis by José M. Diaz-Cruz, Miquel Esteban and Cristina Ariño is part of the series Monographs in Electrochemistry (Ed. Fritz Scholz). This is a valuable reference which gives a complete overview of the chemometric approaches available for electroanalytical data acquisition and treatment, describing the classical methods and emphasizing the specificities related to the electroanalytical field. It has been written by three experienced electrochemists with a special interest in the development of sensors and sensor arrays, and in chemometrics applied to electroanalysis.

Contents The book consists of seven chapters for a total of 192 pages. Chapter 1 provides a brief introduction of the topics. In chapter 2 , the principles of electroanalytical techniques are presented and the different types of data generated are discussed, firstly from the electrochemical point of view (i.e., according to the electrochemical processes involved), and secondly from the chemometric point of view (i.e., according to data dimension). This chapter also reviews the main processes responsible for the non-linearity of electrochemical data. The following four chapters are dedicated to the different chemometric techniques used in electroanalysis, for exploratory data analysis (chapter 3), experimental design and optimization (chapter 4), multivariate calibration (chapter 5), and multivariate curve resolution (chapter 6). Perspectives in the field are outlined in Chapter 7.

\section{Comparison with existing literature}

To the best of my knowledge, this is the unique book giving an exhaustive overview of chemometric techniques applied to the specific and peculiar field of electroanalysis. This is therefore a reference book in the field.

Other books, such as Comprehensive chemometrics (Elsevier, 2009, S. Brown, R. Tauler, B. Walczak Eds) or Applications of the Voltammetry (IntechOpen, 2017, M. Stoytcheva and R. Zlatev Eds) focus on common chemometric techniques or specific electrochemical techniques and contain only one chapter (respectively, Chemometrics in Electrochemistry by M. Diaz-Cruz, Miquel Esteban and Cristina Ariño, updated in 2019, and Applications of Chemometrics-Assisted Voltammetric Analysis by Ali R. Jalalvand) to chemometrics/electroanalysis coupling. 
Critical assessment The book is well-structured and easily readable. It contains 355 references along with numerous figures and tables providing very efficient illustrations of the techniques and methodologies described.

Readership recommendation The book provides basic knowledge of chemometrics for electroanalysts and of electrochemistry for chemometricians with a level of details sufficient for phD students and scientists working in the fields of electroanalysis, especially the development of sensors, and willing to optimize their experiments or to understand how the data they produce may be processed or chemometricians that are asked for help by electrochemists and need to understand what the electroanalytical data represent and how they have been obtained.

Summary The present book is a valuable contribution in the field of chemometrics applied to electroanalysis. The seven chapters give a clear and comprehensive overview of the chemometric tools available for electrochemists willing to optimize analytical procedures and treat data in the most appropriate way to get reliable quantitative informations from a large variety of samples and applications (e.g. development of electrochemical sensors, studies of interactions and equilibria,...). 